УДК 339.166.5

doi: 10.15330/apred.1.17.49-58

Баула О.В.

\title{
ЗАРУБІЖНИЙ ДОСВІД КОМЕРЦІАЛІЗАЦІЇ ІННОВАЦІЙ ТА АКТИВІЗАЦІЇ ІНТЕГРАЦІЙНИХ ПРОЦЕСІВ У ІННОВАЦІЙНІЙ СФЕРІ
}

Луцький національний технічний університет, Міністерство освіти і науки України, кафедра міжнародних економічних відносин, вул. Львівська, 75, м. Луцьк, 43018, Україна, тел.: +380501386599, e-mail: o.baula@Intu.edu.ua, ORCID: 0000-0003-2609-0211

Анотація. Метою статті є моніторинг зарубіжного досвіду комерціалізації інновацій та активізації інтеграційних процесів у інноваційній сфері. Для виконання окресленої мети у процесі дослідження використано методи формалізації, аналогій, аналізу, порівняння. Інформаційною базою дослідження є матеріали Європейської комісії, матеріали монографій, наукових статей вітчизняних і зарубіжних вчених, аналітичних оглядів.

Проведено систематизацію праць вітчизняних та зарубіжних вчених з метою наведення комплексного трактування інновації в сучасних умовах господарювання. Проаналізовано рейтинг країн світу за Глобальним індексом інновацій у 2015-2021 pp. (ТОП-20 та Україна). Досліджено спектр практичних засобів та інструментів задля забезпечення інноваційного розвитку та підвищення рівня комерціалізації інновацій, що застосовують країни світового економічного простору. Оцінивши передовий досвід активізації інноваційної діяльності зроблено висновок про те, що першочерговим завданням, яке вирішують країни-інноваційні лідери $\epsilon$ побудова інноваційного ланцюга від генерації ідеї до іiі реалізації в підприємницькому середовищі.

У статті здійснено узагальнення зарубіжного інтеграційного досвіду фінансового, організаційного i нормативно-правового забезпечення комерціалізації інновацій, а також окреслено заходи даного спрямування, що можуть бути адаптовані для впровадження у вітчизняну інноваційну практику.

Науковою новизною отриманих результатів $\epsilon$ обгрунтування прямого впливу комерціалізації інновацій на конкурентоспроможність країни, уточнено трактування дефініції «інновації» акцентуванням на необхідності їх постійності та безперервності продукування, а також на оптимальності інноваційно-управлінської інфраструктури на мікро-, макро-, мезо- та мегарівнях. Виокремлено із передового зарубіжного досвіду країн - інноваційних лідерів заходи підвищення рівня комерціалізації інновацій для інтегрованих структур (наука, держава, бізнес), що сприятимуть підвищенню ефективності усього ланцюга створення інноваційного продукту у вітчизняній практиці.

Одержані результати дослідження можуть бути використані при формуванні заходів інноваційної політики щодо формування стратегічних напрямів підвищення рівня комерціалізації інновацій.

Ключові слова: інновації, Глобальний індекс інновацій, інноваційний продукт, суб'єкти інноваційної діяльності, start-up компанії, комерціалізація інновацій.

\section{Baula O.V. \\ FOREIGN EXPERIENCE OF COMMERCIALIZATION OF INNOVATIONS AND ACTIVATION OF INTEGRATION PROCESSES IN THE INNOVATION SPHERE}

Lutsk national technical university, Department of International Economic Relations, Lvivska st., 75, Lutsk, 


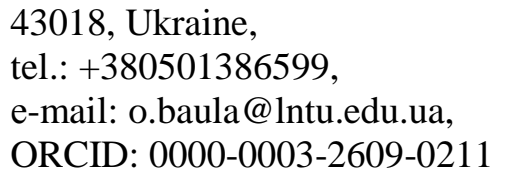

\begin{abstract}
The purpose of the article is to monitor foreign experience in the commercialization of innovations and intensification of integration processes in the innovation sphere. Methods of formalization, analogies, analysis, comparison were used in the research process to fulfill the outlined goal. The information base of the study is the materials of the European Commission, materials of monographs, scientific articles of domestic and foreign scientists, analytical reviews.

The systematization of works of domestic and foreign scientists is carried out in order to provide a comprehensive interpretation of innovation in modern business conditions. The rating of the world countries according to the Global Innovation Index in 2015-2021 (TOP-20 and Ukraine) is analyzed. The range of practical means and tools for ensuring innovative development and increasing the level of commercialization of innovations used by the countries of the World Economic Area has been studied. Assessing the best practices experience of intensifying innovation, it was concluded that the priority task of innovation countries is to build an innovation chain from the generation of an idea to its implementation in the business environment.

The article summarizes the foreign integration experience of financial, organizational and regulatory support for the commercialization of innovations, as well as outlines measures in this area that can be adapted for implementation in domestic innovation practice.

The scientific novelty of the obtained results is the substantiation of the direct impact of commercialization of innovations on the country's competitiveness, the interpretation of the definition of "innovation" is clarified by emphasizing the need for their consistency and continuity of production, as well as the optimality of innovation and management infrastructure at micro, macro and meso levels. Measures to increase the level of commercialization of innovations for integrated structures (science, state, business) have been singled out from the best foreign experience of the countries innovation leaders, which will help increase the efficiency of the whole chain of creating an innovative product in domestic practice.

The results of the study can be used in the formation of innovation policy measures for the formation of strategic directions to increase the level of commercialization of innovations.

Keywords: innovations, Global Innovation Index, innovative product, subjects of innovative activity, start-up companies, commercialization of innovations.
\end{abstract}

Вступ. 3 кожним роком XXI ст. посилюється світова конкуренція, відбувається модернізація технологій, здійснюється структурна перебудова партнерств i стратегічних союзів. Значний рівень динамічності глобальної економічної системи проявляється у підвищенні інтенсивності здійснення інноваційної діяльності, зменшенні тривалості інноваційного процесу та появі нових його суб'єктів. Сучасні тенденції, що прослідковуються в світовій економіці $\epsilon$ досить сперечливими: підвищення інтенсивності інформатизації та автоматизації усіх сфер суспільного виробництва, значне нарощення інтенсивності зростання продажів та капіталізації провідних інформаційно-комунікаційних компаній відбувається одночасно 3 нестабільністю i циклічними кризовими явищами на багатьох ринках, що розвиваються. Деякі дослідники дану ситуацію характеризують як перехідний період, який завершиться новим витком технологічного розвитку. Однак, для забезпечення такого оптимістичного сценарію розвитку подій для країн, що розвиваються доцільно детально вивчити зарубіжний досвід високотехнологічних країн та адекватно його адаптувати до національних реалій в тому числі вітчизняних. Сучасний євроінтеграційний вектор розвитку України може бути успішно зреалізованим лише за умови впровадження соціально-економічних перетворень, в яких чинник інновацій $\epsilon$ безальтернативним. 
Дослідження зарубіжного досвіду побудови високоефективної інноваційної системи знайшли своє відображення в наукових публікаціях вітчизняних та зарубіжних вчених. Це пов'язано зі зростанням ролі чинника інноваційності в стратегіях розвинених держав щодо забезпечення достатнього рівня міжнародної конкурентоспроможності. Фундаментальні дослідження, присвячені вивченню цих питань, знайшли своє відображення в працях вітчизняних та зарубіжних вчених Портер М. [1], Довгаль О. [2], Сиротинська Н. [3], Тихонов Н. [12], Михайлишин Л. [14], Петрова I., Шпильова Т., Сисоліна Н. [15], Бадрі Г., Панченко Є., Рудуха Н. [17], Уолтер А. [18], Маєва А., Зонова О. [19], Лігузова В., Баклаженко Ю. [20].

Однак, подальшого опрацювання потребують питання активізації інтеграційних процесів в інноваційній сфері, адаптації закордонного досвіду комерціалізації інновацій до сучасних умов розвитку України.

Постановка завдання. Основною метою дослідження $\epsilon$ аналіз заходів iз стимулювання комерціалізації інновацій та активізації інтеграційних процесів у інноваційній сфері в країнах - інноваційних лідерах, а також окреслення напрямів активізації інноваційної діяльності в Україні.

Результати. Створення та подальша комерціалізація інноваційних продуктів $\epsilon$ беззаперечним фактом для забезпечення ефективності суспільного виробництва та науково-дослідницької діяльності, особливо за умов постійних трансформацій глобального економічного середовища.

Важливість комерціалізації інновацій підкреслюється Портером М.: «процвітання, особливо в розвинених економіках, випливає із здатності національних компаній створювати, а потім в глобальному масштабі комерціалізувати нові продукти і процеси, освоюючи передові інновації швидше за конкурентів» [1, с. 224].

Науковець Довгаль О. вважає, що у XXI ст. базисом економічного розвитку є не стільки інновації та фундаментальні дослідження на всіх рівнях, а їх комерціалізація [2].

Сиротинська Н. пропонує наступні складові інноваційної діяльності: «аналізування попиту, генерування ідей, виконання науково-дослідних та дослідноконструкторських робіт, оформлення наукових винаходів у вигляді новацій, впровадження новацій у виробництво, комерціалізація інновацій з метою отримання прибутку» [3, с. 401].

Закон України «Про інноваційну діяльність» від 4 липня 2002 року визначає інноваційну діяльність як «діяльність, що спрямована на використання i комерціалізацію результатів наукових досліджень та розробок і зумовлює випуск на ринок нових конкурентоздатних товарів і послуг» [4].

Систематизація праць вітчизняних та зарубіжних вчених дає змогу навести комплексне трактування інновації в сучасних умовах господарювання. А саме, доцільно їх розглядати як результат синтезу нових ідей у процесі НДДКР, які, як правило, мають невипадковий та цільовий характер (для реалізації незадоволених потреб в існуючих або нових ринкових нішах), впроваджені у виробництво та комерціалізовані, потребують інвестицій та оптимальної інноваційно-управлінської інфраструктури, що здійснюються 3 метою покращення конкурентних позицій та отримання комерційного успіху, соціального та екологічного ефекту на мікро-, макро-, мезо- та мегарівнях.

Таким чином, комерційний успіх $є$ базовим показником ефективності інноваційної діяльності.

Найбільш універсальним показником ефективності інноваційних процесів в країні на даний час $є$ Глобальний індекс інновацій (ГІІ). В таблиці 1 наведено значення ГІІ країн-інноваційних лідерів (ТОП-20) та України за 2015-2021 pp. 
Таблиия 1

Рейтинг країн світу за Глобальним індексом інновацій у 2015-2021 рр.

(ТОП-20, Україна)

Ranking of countries in the world according to the Global Innovation Index in 20152021. (TOP-20, Ukraine)

\begin{tabular}{|c|c|c|c|c|c|c|c|c|c|c|c|c|c|c|}
\hline \multirow[b]{2}{*}{ Країна } & \multicolumn{2}{|c|}{2021} & \multicolumn{2}{|c|}{2020} & \multicolumn{2}{|c|}{2019} & \multicolumn{2}{|c|}{2018} & \multicolumn{2}{|c|}{2017} & \multicolumn{2}{|c|}{2016} & \multicolumn{2}{|c|}{2015} \\
\hline & 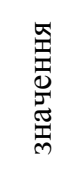 & 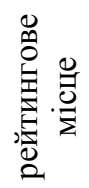 &  & 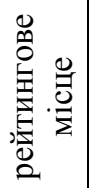 & $\begin{array}{l}\text { 惑 } \\
\text { 兽 } \\
\text { 哥 }\end{array}$ & 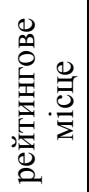 & $\begin{array}{l}\text { 惑 } \\
\text { 兽 } \\
\text { 哥 }\end{array}$ & 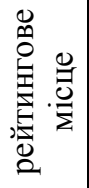 & 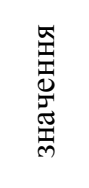 & 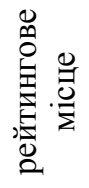 & 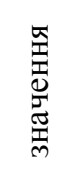 & 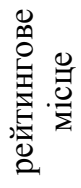 & 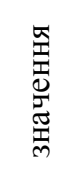 & 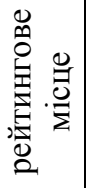 \\
\hline Швейцарія & 65,5 & 1 & 66,1 & 1 & 67,2 & 1 & 68,4 & 1 & 67,7 & 1 & 66,3 & 1 & 68,3 & 1 \\
\hline Швеція & 63,1 & 2 & 62,5 & 2 & 63,7 & 2 & 63,1 & 3 & 63,8 & 2 & 63,6 & 2 & 62,4 & 3 \\
\hline США & 61,3 & 3 & 60,6 & 3 & 61,7 & 3 & 59,8 & 6 & 61,4 & 4 & 61,4 & 4 & 60,1 & 5 \\
\hline $\begin{array}{l}\text { Велика } \\
\text { Британія }\end{array}$ & 59,8 & 4 & 59,8 & 4 & 61,3 & 5 & 60,1 & 4 & 60,9 & 5 & 61,9 & 3 & 62,4 & 2 \\
\hline $\begin{array}{l}\text { Південна } \\
\text { Корея }\end{array}$ & 59,3 & 5 & 56,1 & 10 & 56,6 & 11 & 56,6 & 12 & 57,7 & 11 & 57,2 & 11 & 56,3 & 14 \\
\hline Нідерланди & 58,6 & 6 & 58,8 & 5 & 61,4 & 4 & 63,3 & 2 & 63,4 & 3 & 58,3 & 9 & 61,6 & 4 \\
\hline Фінляндія & 58,4 & 7 & 57,0 & 7 & 59,8 & 6 & 59,6 & 7 & 58,5 & 8 & 59,9 & 5 & 60,0 & 6 \\
\hline Сінгапур & 57,8 & 8 & 56,6 & 8 & 58,4 & 8 & 59,8 & 5 & 58,7 & 7 & 59,2 & 6 & 59,4 & 7 \\
\hline Данія & 57,3 & 9 & 57,5 & 6 & 58,4 & 7 & 58,4 & 8 & 58,7 & 6 & 58,5 & 8 & 57,7 & 10 \\
\hline Німеччина & 57,3 & 10 & 56,5 & 9 & 58,2 & 9 & 58,0 & 9 & 58,4 & 9 & 57,9 & 10 & 57,1 & 12 \\
\hline Франція & 55,0 & 11 & 53,7 & 12 & 54,2 & 16 & 54,4 & 16 & 54,2 & 15 & 54,0 & 18 & 53,6 & 21 \\
\hline Китай & 54,8 & 12 & 53,3 & 14 & 54,8 & 14 & 53,1 & 17 & 52,5 & 22 & 50,6 & 25 & 47,5 & 29 \\
\hline Японія & 54,5 & 13 & 52,7 & 16 & 54,7 & 15 & 55,0 & 13 & 54,7 & 14 & 54,5 & 16 & 54,0 & 19 \\
\hline Гонконг & 53,7 & 14 & 54,2 & 11 & 55,5 & 13 & 54,6 & 14 & 53,9 & 16 & 55,7 & 14 & 57,2 & 11 \\
\hline Ізраїль & 53,4 & 15 & 53,6 & 13 & 57,4 & 10 & 56,8 & 11 & 53,9 & 17 & 52,3 & 21 & 53,5 & 22 \\
\hline Канада & 53,1 & 16 & 52,3 & 17 & 53,9 & 17 & 53,0 & 18 & 53,7 & 18 & 54,7 & 15 & 55,7 & 16 \\
\hline Ісландія & 51,8 & 17 & 49,2 & 21 & 51,5 & 20 & 51,2 & 23 & 55,8 & 13 & 56,0 & 13 & 57,0 & 13 \\
\hline Австрія & 50,9 & 18 & 50,1 & 19 & 50,9 & 21 & 52,0 & 20 & 53,1 & 20 & 52,7 & 20 & 54,1 & 18 \\
\hline Ірландія & 50,7 & 19 & 53,1 & 15 & 56,1 & 12 & 57,2 & 10 & 58,1 & 10 & 59,0 & 7 & 59,1 & 8 \\
\hline Норвегія & 50,4 & 20 & 49,3 & 20 & 51,9 & 19 & 52,6 & 19 & 53,1 & 19 & 52,0 & 22 & 53,8 & 20 \\
\hline Люксембург & 49,0 & 23 & 50,8 & 18 & 53,5 & 18 & 54,5 & 15 & 56,4 & 12 & 57,1 & 12 & 59,0 & 9 \\
\hline Украӥна & 35,6 & 49 & 36,3 & 45 & 37,4 & 47 & 38,5 & 43 & 37,9 & 50 & 35,7 & 56 & 36,5 & 64 \\
\hline
\end{tabular}

Джерело: [5; 6; 7; 8; 9; 10;11].

За значенням Глобального індексу інновацій за 2019-2021 pp. найбільш інноваційними країнами $є$ Швейцарія, Швеція та США. Україна за Глобальним інноваційним індексом за досліджуваний період значно покращила свої позиції (64 місце у 2015p., 49 місце у 2021 р.). За результатами 2021 р. Україна увійшла до трійки країн- лідерів серед інноваційних економік за рівнем доходів нижче середнього рівня.

Очевидним $\epsilon$ твердження про те, що вивчення зарубіжного досвіду країнінноваційних лідерів $є$ питанням на часі для адаптації його до вітчизняних реалій.

Країни - інноваційні лідери застосовують широкий спектр практичних засобів та інструментів задля забезпечення інноваційного розвитку та підвищення рівня комерціалізації інновацій.

Зокрема, у Щвейцарії, яка впродовж тривалого періоду займає першу позицію у світовому рейтингу інноваційного розвитку, функціонує державний регулятор в особі Державної комісії з технологій та інновацій. Основними завданнями даного державного інституту $є$ стимулювання проведення наукових прикладних досліджень, сприяння трансферу підприємств-новачків на ринок інноваційної продукції, формування здорового підприємницького інноваційного середовища в цілому. Однак, 
комерціалізація інновацій в Швейцарії не забезпечується прямими державними інвестиціями. Фінансування інноваційних досліджень, в переважній більшості випадків, здійснюється приватним бізнесом. Нові технології потрапляють у промисловість в основному через мережу технопарків, як інституційних одиниць підтримки підприємництва [12]. В Швейцарії у 2003 р. 3 метою забезпечення ефективного інформаційного обміну між науковим, освітнім і промисловим середовищем створено Асоціацію трансферу технологій «swiTT». Ще однією особливістю швейцарського інноваційного простору $є$ функціонування у вищих навчальних закладах спеціальних центрів трансферу і комерціалізації результатів наукової діяльності.

У Швеції основна увага акцентується на створення єдиного ланцюга формування та трансферу інноваційного продукту «Інноваційний міст» [13], який покликаний забезпечувати комерціалізацію інновацій та їх фінансування. У Швеції до пріоритетних сфер для фінансування науково-дослідних та дослідно-конструкторських робіт належить медицина, біотехнології, сталий розвиток i навколишнє середовище. $\mathrm{y}$ Швеції функціонують «щентри високих технологій», головним завданням яких є об'єднання науково-дослідних і комерційних установ для забезпечення ефективної комерціалізації інновацій.

У США значна роль відводиться державі у підтримці науково-дослідних організацій, венчурного підприємництва, які є основними генераторами інноваційних трансформацій. Особливістю інноваційної стратегії США є орієнтація на забезпечення конкурентних переваг через забезпечення створення новітніх інноваційних продуктів, що не мають аналогів [14, с. 100]. У США сформована чітка система пільг та преференцій для суб'єктів інноваційної діяльності. Так, наприклад, відсутнє оподаткування на оренду для венчурних підприємств, зменшений податок на прибуток для організацій із цінними паперами венчурних фірм, гарантовані субсидії венчурному бізнесу, пільгове оподаткування інноваційних фірм, обов'язкове залучення венчурних структур до виконання значних за обсягами інноваційних проектів і т.п. [15, с. 186].

Інноваційна діяльність в США характеризується повною підприємницькою автономією в межах якої у структурі корпорацій можуть створюватись венчурні відділи, функціями яких є створення необхідних умов для реалізації інноваційних ідей. Фінансування інновацій в США відбувається за рахунок корпоративних та фондових коштів. Так, у США для забезпечення ефективності процесу комерціалізації технологій сформована національна мережа передачі технологій, фінансова підтримка яким надається промисловими компаніями, які зацікавлені в технологічних розробках. Для формування фундаментальної бази НДДКР, а також 3 метою забезпечення конкурентоспроможності та незалежності економіки від зарубіжних технологій, в США реалізуються національних програми «Програма підтримки інноваційних досліджень малого бізнесу» i «Програма по поширенню технологій малого бізнесу», які координуються відділом технологій «Адміністрації Малого Бізнесу» (SBA).

Цікавим $\epsilon$ досвід Великобританії у сфері активізації інновацій. В країні реалізується ряд програм, що спрямовані на підтримку впровадження новинок науки i техніки у виробництво (Medici, Mercia, Enterprise Fellowshipscheme, Connect та ін.), а також створена та діє ефективна система пільг та преференцій для венчурних компаній:

- податок на прибуток стягується у розмірі $25 \%$ на противагу $35 \%$ для решти суб'єктів господарювання;

- кошти, що надаються венчурним підприємствам підлягають обов'язковому страхуванню;

- держава гарантує субсидування інноваційних витрат малих підприємств (до $50 \%)$ 
Актуальні проблеми розвитку економіки регіону. Вип 17. T.1

- гарантована участь малих інноваційних фірм в урядових замовленнях на науково-дослідні та дослідно-конструкторські розробки [15, с. 188]

Також у Великобританії за підтримки держави створено систему Університетських інноваційних центрів, які сприяють трансферу технологій між вузами і промисловістю [4].

32016 року до ТОП-10 країн-лідерів за Глобальним індексом інновацій належить Німеччина. В країні з 2006 року реалізується Стратегія інноваційного та технологічного розвитку, згідно якої інструментом урядової політики стали створені альянси і партнерства інноваційного спрямування, основним функціями яких $є$ формування раціонального механізму підтримки інноваційної активності переважно в промисловості. Характерною рисою німецької інноваційної системи є функціонування наукових товариств та дослідницьких асоціацій. Для прикладу доцільно згадати Фраунгоферовське товариство до складу якого входить близько 60 інституційних суб'єктів, що забезпечують проведення наукових досліджень та впровадження їх результатів у промисловість. В Німеччині організовано близько 200 подібних асоціацій. Концепція, джерела і форми фінансування інноваційних розробок $є$ досить різними, все залежить від рівня пріоритетності інноваційної розробки.

Оцінюючи західноєвропейський досвід активізації інноваційної діяльності очевидним є твердження про те, що першочерговим завданням яке вирішують країниінноваційні лідери $є$ побудова інноваційного ланцюга від генерації ідеї до іiї реалізації в підприємницькому середовищі. Функціонування центрів трансферу технологій також $\epsilon$ загальноєвропейською практикою. Вони створюються на базі вузів або ж як окремі інститути. Сильними сторонами діяльності центрів трансферу технологій є створення нових інноваційних підприємств задля забезпечення трансферу технологій.

Згідно дослідження Європейської комісії існують наступні типи науковоінтеграційних об'єднань в країнах Європи:

1) технологічні start-up компанії;

2) науково-дослідні академічні та корпоративні spin-off компанії;

3) компанії, що адаптують технології під ринкові запити;

4) технологічні spin-inn компанії [16].

Здійснюючи дану класифікацію Європейська комісія керувалась наступними тезами:

- одна частина інноваційних компаній у своїй діяльності базуються на перспективних технологічних платформах, тоді як інші - на комбінуванні і модернізації вже існуючі технології;

- одна частина високотехнологічних підприємств розвиває технології на вже існуючих ринках, тоді як інша - орієнтується на розвиток ринків через застосування існуючих технологій [16].

На теренах Європи набули поширення три типи start-up компаній (рис. 1). 


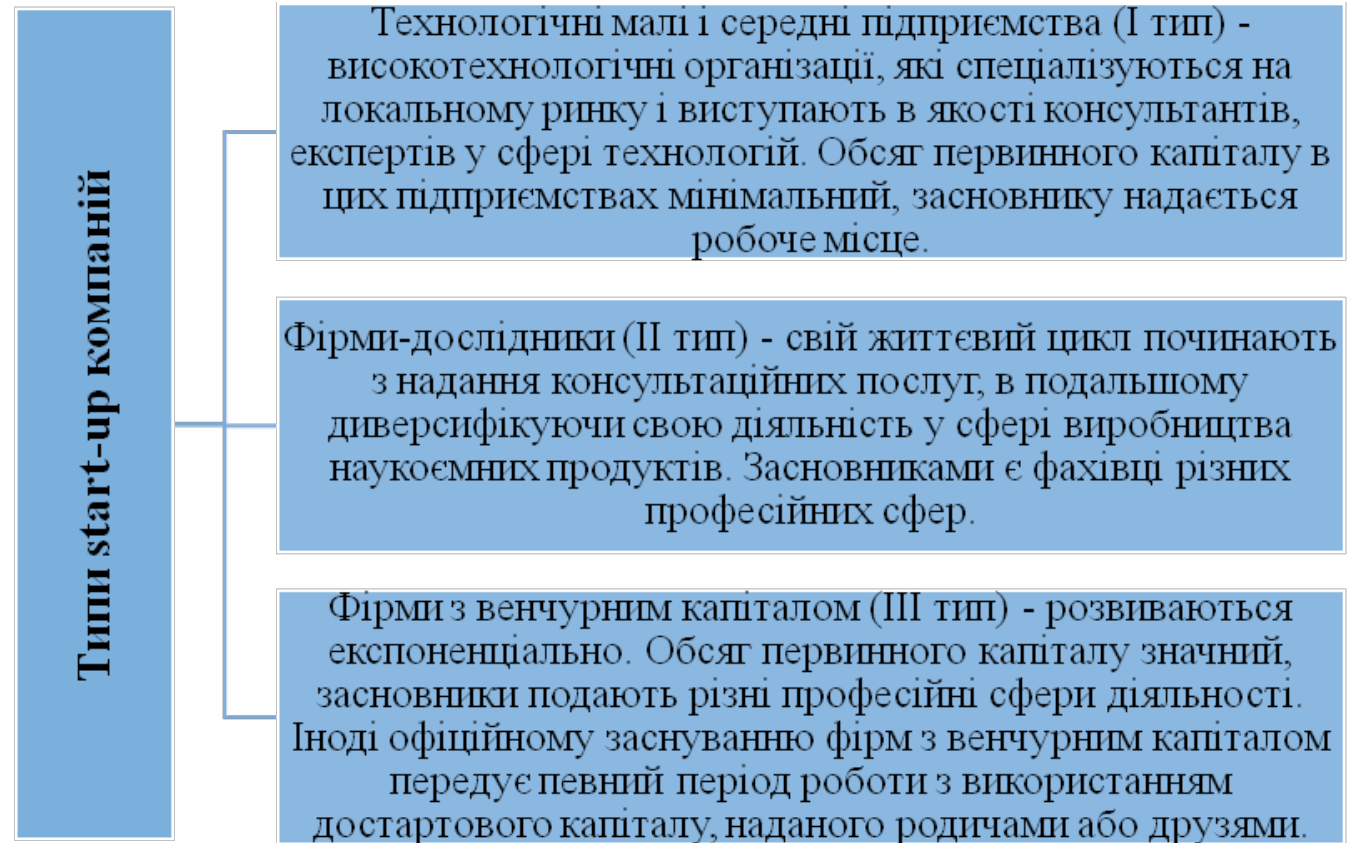

Puc. 1. Типи start-up компаній: європейський досвід

Fig.1.Types of start-up companies: European experience

Джерело: складено за [17; 18, с. 228-234].

Узагальнення зарубіжного інтеграційного досвіду фінансового, організаційного і нормативно-правового забезпечення комерціалізації інновацій представлено на рис. 2 .


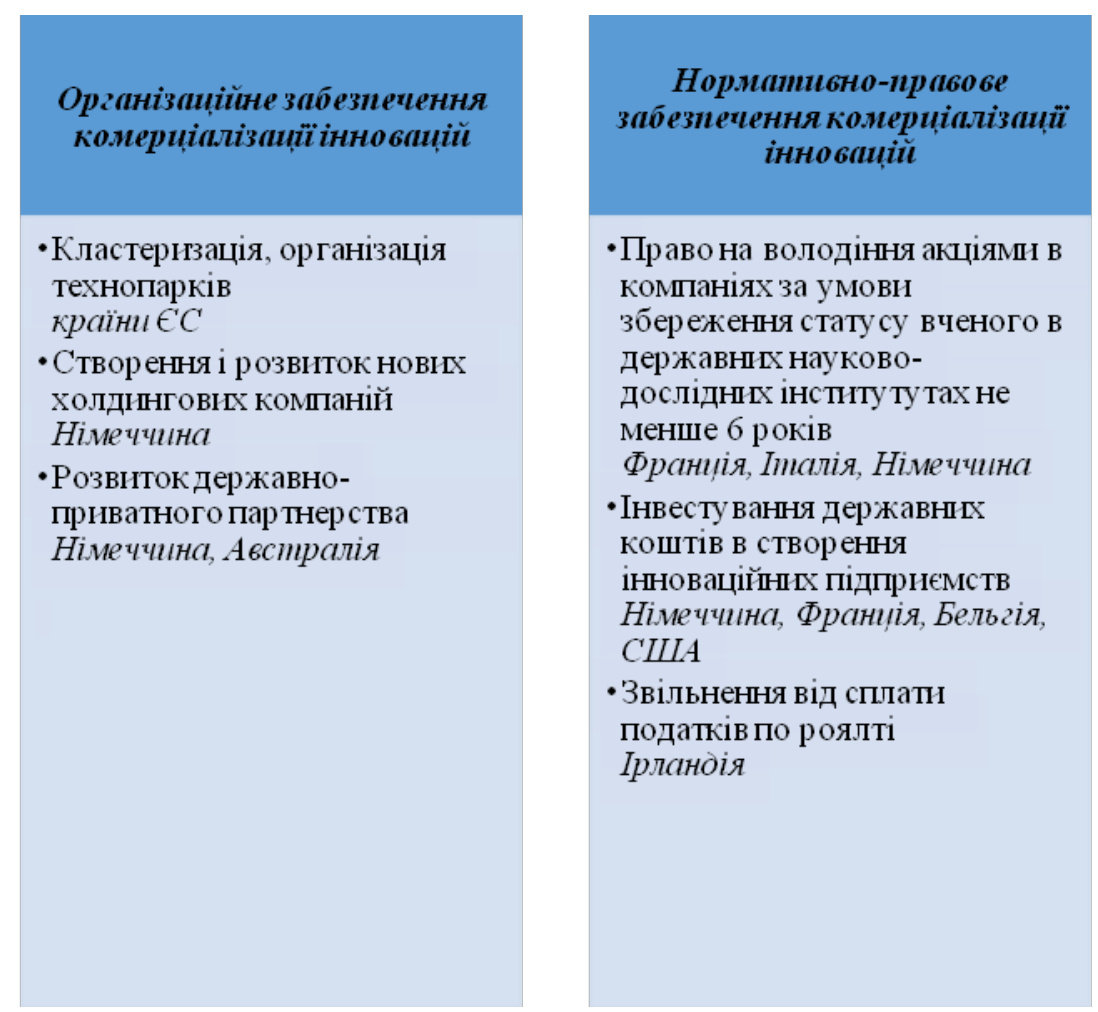

Puc. 2. Узагальнення зарубіжного досвіду сприяння комерціалізації інновацій Fig. 2. Generalization of foreign experience in promoting the commercialization of innovations

Джерело: складено за [14; 19; 20]. 
За інтегральним показником Глобального індексу інновацій Україна за період 2015-2021 рр. загалом покращувала свої позиції (64 рейтингове місце у 2015 р., 49 місце у 2021 р.). Зокрема, позитивну динаміку можна прослідкувати за підіндексом щодо розвитку бізнесу та результатами креативної діяльності. Інші структурні елементи Глобального індексу інновацій за досліджуваний період демонстрували не настільки втішну ситуацію. Стабільно низькі позиції спостерігаємо за підіндексом «Стан інституційного середовища», «Стан розвитку людського капіталу та науки», «Розвиток інфраструктури», «Розвиток внутрішнього ринку» $[5 ; 6 ; 7 ; 8 ; 9 ; 10 ; 11]$.

3 проведеного дослідження доцільно зробити висновок про те, що Україна має високий науковий і освітній потенціал, який має усі можливості продукувати нові ідеї та наукові розробки, але одночасно спостерігається низька ефективність механізму впровадження їх у сферу економічної діяльності. Саме тому, насамперед, потребує розробки механізм комерціалізації результатів інноваційної діяльності та створення ефективного інституційного середовища, яке забезпечить підвищення рівня людського розвитку.

Висновки. Таким чином, аналіз зарубіжного досвіду комерціалізації інновацій дає змогу окреслити заходи фінансового, організаційного та нормативно-правового забезпечення, що можуть бути корисними для впровадження у вітчизняну інноваційну політику:

- перетворення високотехнологічного промислового комплексу на полюс зростання вітчизняної економіки;

- розширення участі і підтримки держави у забезпеченні інноваційної активності в країні через використання різних форм фінансово-організаційного забезпечення: розробка дієвої системи податкових пільг для суб'єктів інноваційної діяльності, пряме інвестування інноваційної діяльності, реалізація системи державних замовлень і закупівель;

- забезпечення інтеграційної взаємодії науки, освіти, бізнесу та держави;

- забезпечення розвитку інноваційної інфраструктури через ефективнофункціонуючу мережу кластерів, технопарків, бізнес-інкубаторів і т.п.;

- створення дієвої системи мотивації для залучення малих підприємств до інноваційної діяльності (програми фінансування малих та середніх підприємств, кредити на інноваційні цілі на пільгових умовах, державне гарантування субсидування інноваційних витрат малих підприємств, гарантування участі малих інноваційних фірм в урядових замовленнях на НДДКР і т.п.);

- використання на інноваційних підприємствах внутрішнього технологічного аудиту;

- прискорення інноваційних процесів через активне використання інформаційнокомунікаційних технологій;

- активізація використання в управлінні інноваційними процесами методів бенчмаркінгу, контролінгу і техніко-економічного аналізу і т.п.

1. Портер М. Конкурентное преимущество: как средство высокого результата и обеспечения его устойчивости. М.: Альпина Бизнес Букс, 2015. 427 с.

2. Довгаль О.А. Інноваційний розвиток економіки: методологія аналізу. Вісник Університету банківської справи Національного банку України 2013 № 1 (16). URL: http://nbuv.gov.ua/UJRN/VUbsNbU_2013_1_23 (дата звернення: 26.07.2020).

3. Сиротинська Н. М. Зародження та розвиток теоретичних основ інновацій. Вісник Національного університету «Львівська політехніка». 2011. № 714: Менеджмент та підприємництво в Україні: етапи становлення і проблеми розвитку. С. 399-405.

4. Закон України «Про інноваційну діяльність» від 04.07.2002 p. № 40-IV. ВВРУ. 2002. № 36. C. 266. URL: https://zakon.rada.gov.ua/laws/show/40-15\#Text (дата звернення: 26.07.2020). 
5. Global Innovation Index 2015. Effective Innovation Policies for Development. URL: https://www.wipo.int/edocs/pubdocs/en/wipo_gii_2015.pdf (дата звернення: 29.03.2020).

6. Global Innovation Index 2016. Winning with Global Innovation. URL: https://www.wipo.int/edocs/pubdocs/en/wipo_pub_gii_2016.pdf (дата звернення: 29.03.2020).

7. The Global Innovation Index 2017. Retrieved from. URL: http://www.wipo.int/publications/en/details.jsp?id=4193\&plang=EN (дата звернення: 29.03.2019).

8. Global innovation index - 2018. URL: https://www.wipo.int/edocs/pubdocs/en/wipo_pub_gii_2018.pdf (дата звернення: 29.03.2020).

9. Global innovation index - 2019. Creating Healthy Lives-The Future of Medical Innovation. URL: https://www.wipo.int/edocs/pubdocs/en/wipo_pub_gii_2019.pdf (дата звернення: 29.03.2019).

10. Global Innovation Index 2020. Who Will Finance Innovation? URL: https://www.wipo.int/edocs/pubdocs/en/wipo_pub_gii_2020.pdf (дата звернення: 10.10.2021).

11. Global Innovation Index 2021. Tracking Innovation through the COVID-19 Crisis. URL: https://www.wipo.int/edocs/pubdocs/en/wipo_pub_gii_2021.pdf (дата звернення: 10.10.2021).

12. Тихонов Н.А. Эффективность способов коммерциализации инноваций. Управление экономическими системами. URL: http://www.uecs.ru/uecs40-402012/item/1271-2012-04-19-06-35-15 (дата звернення: 03.05.2021).

13. Обзор международного опыта инновационного развития. URL: https://www.nanonewsnet.ru/articles/2011/obzor-mezhdunarodnogo-opyta-innovatsionnogo-razvitiya (дата звернення: 10.10.2021).

14. Михайлишин Л.І.Зарубіжний досвід активізації інноваційної діяльності. Науковий вісник Ужгородського національного університету. Серія: Міжнародні економічні відносини та світове господарство. 2016. Випуск 6, частина 2. С. 99-104. URL: http://www.visnykeconom.uzhnu.uz.ua/archive/6_2_2016ua/25.pdf (дата звернення: 03.05.2021).

15. Інноваційна діяльність: стимули та перешкоди: [монографія] / І.Л. Петрова, Т.І. Шпильова, Н.П. Сисоліна; за наук. ред. проф. І.Л. Петрової. К.: Дорадо, 2010. 320 с.

16. Euratex. URL: euratex.eu (дата звернення: 14.10.2021).

17. Бадрі Г., Панченко Є., Рудуха Н. Глобальні детермінанти і моделі фінансування інновацій. Міжнародна економічна політика. 2018. № 1 (28). http://iepjournal.com/journals/28/2018_1_\%20Badri_Panchenko_Rudukha.pdf (дата звернення: 14.10.2021).

18. Айзексон Уолтер. Инноваторы. Как несколько гениев, хакеров и чиков совершили цифровую революцию/Пер. с анг. М.: Издательство ACT: CORPUS, 2015. 616 с.

19. Маева А.С., Зонова О.В. Проблемы коммерциализации инноваций на пути построения инновационной модели экономики. URL: http://nisse.ru/articles/details.php?ELEMENT_ID=129462 (дата звернення: 14.10.2021).

20. Лігузова В.О., Баклаженко Ю.В., Гиря Р.М. Світовий досвід державної підтримки інновацій. Глобальні та національні проблеми економіки. 2017. Випуск 18. URL: http:/globalnational.in.ua/archive/18-2017/10.pdf (дата звернення: 17.10.2021).

\section{References}

1. Porter, M. Competitive advantage: as a means of high performance and ensuring its sustainability. Alpyna Byznes Buks, 2015.

2. Dovhal, O. A. "Innovative economic development: methodology of analysis." Visnyk Universytetu bankivskoi spravy Natsionalnoho banku Ukrainy, no. 1(16), 2013, nbuv.gov.ua/UJRN/VUbsNbU_2013_1_23. Accessed 26 July 2020.

3. Syrotynska, N. M. "Origin and development of theoretical foundations of innovation." Visnyk Natsionalnoho universytetu «Lvivska politekhnika», no. 714, 2011, pp. 399-405.

4. "About innovative activity. The Law of Ukraine.” Verkhovna Rada of Ukraine, zakon.rada.gov.ua/laws/show/40-15\#Text. Accessed 26 July 2020.

5. “Global Innovation Index 2015. Effective Innovation Policies for Development." WIPO, www.wipo.int/edocs/pubdocs/en/wipo_gii_2015.pdf. Accessed 26 July 2020.

6. “Global Innovation Index 2016. Winning with Global Innovation.” WIPO, www.wipo.int/edocs/pubdocs/en/wipo_pub_gii_2016.pdf. Accessed 27 July 2020.

7. "The Global Innovation Index 2017. Retrieved from.” WIPO, www.wipo.int/publications/en/details.jsp?id=4193\&plang=EN. Accessed 27 July 2020.

8. “Global innovation index - 2018.” WIPO, www.wipo.int/edocs/pubdocs/en/wipo_pub_gii_2018.pdf. Accessed 27 July 2020.

9. “Global innovation index - 2019. Creating Healthy Lives—The Future of Medical Innovation.” WIPO, www.wipo.int/edocs/pubdocs/en/wipo_pub_gii_2019.pdf. Accessed 27 July 2020. 
10. “Global Innovation Index 2020. Who Will Finance Innovation?” WIPO, www.wipo.int/edocs/pubdocs/en/wipo_pub_gii_2020.pdf. Accessed 27 July 2020.

11. “Global Innovation Index 2021. Tracking Innovation through the COVID-19 Crisis.” WIPO, www.wipo.int/edocs/pubdocs/en/wipo_pub_gii_2021.pdf. Accessed 27 July 2020.

12. Tykhonov, N. A. "Effectiveness of ways to commercialize innovations." Upravlenye ekonomycheskymy systemamy, www.uecs.ru/uecs40-402012/item/1271-2012-04-19-06-35-15. Accessed 28 Sept. 2021.

13. "Review of international experience in innovative development." Nanonewsnet, www.nanonewsnet.ru/articles/2011/obzor-mezhdunarodnogo-opyta-innovatsionnogo-razvitiya. Accessed 28 Sept. 2021.

14. Mykhailyshyn, L. I. “ Foreign experience in intensifying innovation.” Naukovyi visnyk Uzhhorodskoho natsionalnoho universytetu. Seriia: Mizhnarodni ekonomichni vidnosyny ta svitove hospodarstvo, no. 6/2, 2016, pp. 99-104, www.visnyk-econom.uzhnu.uz.ua/archive/6_2_2016ua/25.pdf. Accessed 28 Sept. 2021.

15. Petrova, I. L., Shpylova, T. I., Sysolina, N. P. Innovation: incentives and barriers. Kyiv, Dorado, 2010.

16. Euratex, euratex.eu. Accessed 14 Oct.2021.

17. Badri, H., Panchenko, Ye., and N.Rudukha. "Global determinants and models of innovation financing." Mizhnarodna ekonomichna polityka, no. 1 (28), 2018, iepjournal.com/journals/28/2018_1_ \%20Badri_Panchenko_Rudukha.pdf. Accessed 14 Oct. 2021.

18. Aizekson, Uolter. Innovators. Like several geniuses, hackers and chicks, they made a digital revolution, ACT: CORPUS, 2015.

19. Maeva, A. S., and O. V. Zonova. " Problems of commercialization of innovations on the way to building an innovative model of the economy.” Nisse, nisse.ru/articles/details.php?ELEMENT_ID=129462. Accessed 17 Oct.2021.

20. Lihuzova, V. O., Baklazhenko, Yu. V., and R. M.Hyria. “ World experience of state support of innovations.” Hlobalni ta natsionalni problemy ekonomiky, no. 18, 2017, globalnational.in.ua/archive/18-2017/10.pdf. Accessed 17 Oct. 2021. 